\title{
A Content Analysis of Textbooks: Investigating Gender Bias as a Social Prominence in Iranian High School English Textbooks
}

\author{
Abdullah Gharbavi \\ English Department of Linguistics and Foreign Languages \\ Khoramshahr Payam-e-Noor University, Iran \\ Tel: 98-939-766-9153Ｅ-mail: agharbavi7777@gmail.com \\ Seyyed Ahmad Mousavi \\ English Department of Linguistics and Foreign Languages \\ Tehran Payam-e-Noor University, Iran \\ Tel: 98-916-634-0048_E-mail: mosaviahmad55@yahoo.com
}

Received: May 3, 2012

doi:10.5430/elr.v1n1p42
Accepted: May 23, 2012

Online Published: June 5, 2012

\begin{abstract}
This paper aims to look at language gender bias in EFL textbooks. It is the second in a series of three complementary papers which look at sexism (see Gharbavi \& Mousavi, 2012). All use the same corpus; however different methodology. The paper points to areas that remain problematical in the design of textbooks. Four English textbooks currently taught in the Iranian high schools were chosen as a sample of this study. Three categories in these textbooks were examined: male and female visibility in illustrations, texts and the male/female occupational roles. First, a content analysis was conducted on the data, and then the frequency of each category was calculated and compared with one another. The results of chi-square test indicated that there is a significant difference between the frequencies of male and female for different categories of this study. The findings are followed by analysis and interpretation with special attention given to the relationship between language sexism and ideology. Pedagogical implications of the study have been discussed.
\end{abstract}

Keywords: Sexism, Gender-biased language, Stereotyped sex roles, Occupational roles, Visibility in texts

\section{Introduction}

Gender-biased language in textbooks can affect students adversely and it creates an oppressive world for them because this gender-biased language most often is unjustified and unfair (Cameron, 1990, p. 13). Studies of gender and language have found that gender bias and gender stereotypes in written text and pictures have deleterious effects for female students (Lesikin, 2001, p. 281). These effects include feelings of exclusion, devaluation, alienation and lowered -expectations. We believe that there are a lot of textbooks which represent females only as housewives or show fewer females than males in their texts and illustrations. ESL/EFL materials reflect the opinions and attitudes of their authors and developers.

Educators are concerned about sexism and writers' attitudes in textbooks because some textbooks may have destructive effects on students' personality. For example, preponderance of males in the math textbooks may suggest to female students that mathematics is not really for them. A biased representation of female and male can lead to students' sense of what is normal for women and men in our society. In other words, the content of the textbooks helps reinforce gender as a social division and perpetuate inequalities between men and women. Experts and authorities in education also believe that the health and mental, social, cultural and scientific growth of every learner depends on a balanced and appropriate system of education. Books are part of this appropriate curriculum (Kemp, 1977, p. 17). The content of the books contains the most essential executive policy for achieving the targets of every educational system. That is why it is essential to develop accurate and scientific-based textbooks. Textbooks play important roles in determining the educational content and policy. Thus, they have been the focus of education authorities, textbook designers, researchers and teachers' attention. 
Education authorities have suggested diverse criteria for selecting appropriate and efficient content of the textbooks. One of these is that the content of the textbooks should be consistent with and relevant to the sex of the intended learners (Eisner, 1985, pp. 201-202). The content of textbooks is useful and efficient when it is consistent with the learner's age and sex. Therefore, the content of the textbooks, that is, the issues, sentence models and examples must be represented in such a way that both male and female learners feel that they are equally valuable for society. Textbooks should not impose on the readers (students) the idea that male students have more social prominence than females. However, a glance at the current EFL textbooks reveals a gender-biased approach in the design of the book contents. There seems little balance and equality between male and female students in the content of the textbooks. According to Graci (1989, p. 79), the lack of equality in gender presentation is one of the most frequent problems of published books. Some researchers of ESL textbooks (Porreca, 1984; Lesikin, 2001, among others) have shown them to contain gender bias.

Then analysis of the content of ESL/EFL textbooks is of utmost importance if we want to find out whether the content is interesting, offensive, fair or discriminatory (Byrd, 2001, p. 417). Hall \& Hewing (2001, p. 1) believe that analysis of content of ESL/EFL books is a key contemporary issue in English language teaching and applied linguistics. However, this area of research has received little attention in our country, especially from social perspectives. Many of the previous EFL textbooks research evaluated the efficacy of the books and their methodology of presentation of materials and exercise rather than social aspects of textbooks (Crawford, 2002, p. 81). The present study sought to identify the relative social prominence of female and male in Iranian EFL textbooks of high school. It also attempted to determine the relative frequency of gender -biased pictures. So this study tried to find answer to the fowling questions:

1) Are males more visible than females both in texts and pictures?

2) Do males enjoy more occupational roles than their counterparts? In other words, do men enjoy more diversity in their jobs and women are depicted to work in only limited types occupational roles?

\section{Review of the literature}

Speech and writing have malign power to disguise important truth in a cloud of misleading rhetoric (Cameron, 1992, p.1). In the same vain, Bolinger (1980, p. 68) believes that language is a weapon, used by the powerful to oppress and silence their subordinates. To our understanding, sexist language has similar malign power that Cameron and Bolinger refer to.

The sex issue was not only the concern of the feminists as a social practitioners ,but also the concern of the linguists who were concentrating on language phenomena such as women's access to words, their representation in languages well as naming practices (Cameron,1990;Pauwel,1998).

The issue of sex treatment in textbooks has received considerable attntion (Porreca, 1984; Peterson \& Kroner, 1992; Reese, 1994; Ansary \& Babii, 2003). Arnold-Gerrity (1978) performed a content analysis of a 1976 series of primary reading textbooks, examining the visibility of female characters. She found that in the first four textbooks, for grades one and two, there were twice as many male-oriented stories as female-oriented ones. In grades three and four, male-oriented stories were five times as frequent, and in the two textbooks for grades five and six, there were three times as many male-oriented as female-oriented stories. She also found that men were portrayed in four times as many paying occupation as women and that the females were most frequently portrayed in a house-wife mother capacity, occupied with household tasks and serving their children and husbands.

Deliyanni-Kouimtzi (1992) explored the occupational roles of men and women in Greek primary school books and found that these textbook contain more working women after principles of gender equality were applied in eduction. However, only $13.6 \%$ of women are portrayed as paid workers as opposed to $53.2 \%$ of men (p.77).

In another study, Peterson and Kroner (1992) investigated gender bias in textbooks for psychology and human development . They demonstrated that representation of work and behavior of males significantly exceeds the representation of female. Females on the other hand, are frequently portrayed in negative and gender- biased ways (pp. 34-35)

Hartman and Judd (1978) reviewed several then-current TESOL textbooks. They examined the images of women and men, firstness (the order of female-male mention), and stereotyped roles for females and males. For each category, they found that the ESL materials reflected sexist attitudes and values. Women were underrepresented in the textbooks; the worst ratio of males to females was 73 percent to 27 percent. Occupational roles for women were traditional and limited, with very limited number of token professionals; on the other hand, those for men were quite varied. Hartman \& Judd also found that masculine generic construction were used more often than feminine generic 
constructions in the textbooks. In general, throughout the textbooks, stereotyped sex roles were rampant, including the over-emotional female; house work and child care as female-exclusive domains; passive, weak female children; and active, bold male children. Women were generally portrayed as selfish and superficial, while men were cast as helpful and patronizing (Hartman \& Judd, 1978, p. 390-391).

Nilson (1997) analyzed words for males and females found in a standard dictionary. She found that there were more than five times as many words for males as there were for females.

Porreca (1984) investigated how sexism is manifested in ESL textbooks. She analyzed the content of 15 widely-used ESL textbooks, focusing on the categories of (1) omission ratio of females, compared to males, in text and illustration, (2) firstness, (3) occupations, (4) frequency of male nouns to female nouns, (5) generic masculine nouns and pronouns (man/he) and (6) types and frequency adjectives for men and women. She found that "there is evidence that sexism continues to flourish in ESL textbooks' (Porreca, 1984, p. 718). She reported that 'although females comprise slightly over half the population of the United States, they are represented only half as often as males in both text and illustration'.

Most recently, in our country (Iran), Ansary and Babaii (2003) explored the status of sexism in current ESL/EFL textbooks. They performed two types of analyses (quantitative and qualitative) to examine the manifestations of sexist attitudes and values in two textbooks (Right Path to English I and II) which were locally designed to cater for and respond to the English language needs of Iranian students at guidance schools. They found that 'women suffered most obviously from low visibility' (Ansary \& Babaii, 2003, p. 69). The ratio of females to males was 1 to 1.4 in text and 1 to 1.6 in illustrations. They found that of the total 40 topics in dialogues, 27 topics were male-dominated ones.

\section{Methodology}

\subsection{Materials}

Four current EFL/ELT textbooks, i.e. English Book 1, 2, 3, and Learning to Read English for Pre-university Students that are locally designed to cater for and respond to the English language needs of the Iranian students at high school are selected to serve as the corpus of the present study.

\subsection{Data collection procedures}

To collect the data for this study, the researchers went through the following steps in order. First, the textbooks were selected. Then, these textbooks were examined and studied in depth. This step of content analysis is called mass observation the result of which will be newly categorized hypotheses (Cohen \& Manion, 1992, p. 49). In content analysis tradition, the researcher has to do two mass observations: the first one is done after choosing the documents (textbooks). The purpose of the first phase is to have a cursory look at the textbooks in order to make sure that the documents contain the data that the researcher is looking for. After the researcher has observed the textbooks, he or she will divide the textbook contents into different divisions, such as occupational roles, social activities, home chores, etc., and then carries out the second mass observation of the content analysis. This second phase of the content analysis is meant to serve the purpose of modifying the original hypotheses which have been formulated before dividing the content into different divisions, such as occupational roles and home chores (ibid). Therefore, the original hypotheses and purpose of the study were modified slightly after mass observation. After the textbooks were observed, different categories were chosen for investigation. Finally, the frequencies of each category were counted in the form of a content analysis.

\subsection{Data analysis procedures}

To analyze the quantitative data the following descriptive statistics are used: a) frequency and percentage and b) chi-square to examine whether there are statistically significant differences between sex and different categories of the study. All the hypotheses are set at the 0.05 level of probability.

Also as a qualitative analysis, the inferences underlying messages of text based on the presence or absence of some evidence in the text are put forward. To be more precise, qualitative analysis will be made in to (a) stereotype sex roles, (b) firstness (c) Male/female job types, (d) sex-biased activity types, (e) masculine generic constructions and (f) attributions (adjectives) of males and females.

\section{Results}

In order to present the quantitative data easily, first the frequencies and percentages were collected and summarized, and then to help explain differences in the number of males and females, chi-square test was used to ascertain if there were significant differences between the number of males and females in different categories of this research. 
Table 4.1 displays the frequencies and percentages of males and females' visibility in the reading passages of four high school English textbooks. As the table shows, there are apparently considerable differences between the number of males and females in the reading passages of the textbooks (Table 4.1, at the end of this article).

As shown in table 4.2 the frequencies of males' visibility is greater than females' visibility in the pictures of the textbooks. Males' visibility is nearly three times as much as that of females. $76 \%$ of the pictures show males whereas $24 \%$ of the pictures display female personalities.

An examination of males and females' occupational roles demonstrated that only $18 \%$ females were portrayed in occupational roles; however, for the males this was $82 \%$ (Table 4.3 ).

\section{Discussion}

\subsection{Visibility in texts and illustrations}

The findings confirmed our hypothesis that males are more visible than females in texts and pictures (Tables 4.1 and 4.2). Chi-square tests were then applied to the data shown in these tables. Table 5.1 and Table 5. 2 show the outcome of the tests. Then, the obtained results were evaluated against the sampling distribution of chi-square table. The chi-square distribution depends upon degrees of freedom. For chi-square test, degree of freedom is defined as K-1, where $\mathrm{K}$ stands for the number of categories. We have two categories (male and female), leaving 2-1=1df. From the chi-square table, it is easily seen that at the .05 level and with 1 degree of freedom the critical Chi-square is 3.84 . Since the obtained Chi-squares (108.28 and 99.34 in Tables 5.1 and 5.2) are greater than 3.84 in the Chi-square table, we can safely accept the hypothesis that males are more visible than females both in texts and illustrations.

The females' low visibility can be attributed to the writers' ideology. The writers may consider women as unequal to men. They may believe that women cannot play determining roles in their society, due to their physical or psychological nature. Accordingly, we assume that the writers avoided depicting women as determining personalities; consequently, they excluded them from mainstream society, and refrained from endowing women their right to be represented as much as men.

Some Western sociologists ascribed the low visibility of women in the textbooks content and in our society in general- to the occurrence of Islamic revolution in Iran in 1979. For example, Streans (2000, p. 130) argues that, after the Islamic revolution in Iran, women were not allowed fulltime jobs and women's opportunity in education also reduced. This idea can be refuted by looking at women's education statistics, however. The women education had considerable improvement from1976 to1991. Almost half of women population was uneducated before the Islamic revolution of Iran. According to statistics in 1976 only 4 million of women population was enjoying literacy in Iran. During a period of 10 years, the number of educated women doubled and reached 8 million people. Finally, in 1991, there were 14 million women who were able to read and write (Kadivar, 1996, pp. 155-156). Thus, low visibility of women in textbook content, pictures and our society in general may not be attributable to the Islamic revolution in Iran.

Some people argue that Islam and the Holy Koran give priority to men over women in enjoying certain rights and consider men superior to women. These people refer to Verse 228 of the Chapter entitled Baqara as evidence to their argument. While this verse declaring women to enjoy certain rights and responsibilities, the impression is created that men are ranked higher in comparison with women:

لهن مثل الذى عليهن با المعروف اللرجال عليهن درجه

Translation: They (women) have rights (over their husbands as regards living expenses) similar to those of their husbands over their wives (as regards obedience and respect) to what is reasonable, but men have a degree (of responsibility) over them.

The present researchers cannot agree with this argument. From the standpoint of Islam and Koran, women are mainly considered as a complete human being who have been created from the same source as men and are complementary to men. To show that our argument is a valid one, we have to refer to Verse 1 of Nesa and Verse 72 of the Chapter called An-Nahl:

يا ايها الناس اتقو ا ربكم الذى خلقكم من نفس و احده وخلق منها زوجها.

Translation: O mankind! Be dutiful to your Lord, who created you from a single person (Adam), and from him (Adam) God created Adam's wife.

$$
\text { و الله جعل لكم من انفسكم ازو اجأ وجعل لكم من ازو اجكم بنين وحفذه. }
$$


Translation: And God has made mates (wives) of your own kind, and has made for you, from your wives, sons and grandsons.

In Islam religion, there is no superiority or priority in being a man or woman. The most superior and honorable person is one who is pious and believes in God. According to verse 13 of the Chapter called Al-Hujurat, piety of people and not their sex is introduced as the superiority of people:

يا ايها الناس انا اخلقنكم من ذكر وانثى وجعلنكم شعوبا وقبائل لتعارفون ان اكرمكم عند الله اتقئكم ان الله عليم خبير

Translation: O mankind! We have created you from a male and a female, and you into nations and tribes, that you may know one another. Verily, the most honorable of you with Allâh is that (believer) who has At- Taqwâ (piety). Verily, Allah is all-knowing, Well-Acquainted (with all things).

\subsection{Male and female occupational roles}

It was hypothesized that males enjoy more diverse occupational roles than those of females. In order to test this hypothesis, a Chi-square test was applied to the data shown in Table 4.3. The result of this test is presented in Table 5.3 (see the end of this article).

Since the obtained Chi-square (34.76) is greater than 3.84 in the chi-square Table, we can conclude that the difference between the observed and expected frequencies is significant and the hypothesis is accepted at the 0.05 level of probability.

Women's limited roles may also have causal association with the writers' culture. A culture embodies and sustains social values attached to male or female and it shapes people's expectations about what types of jobs men and women should do and how they should behave.

One other possible reason why women occupation is limited may be ascribed to gender stereotypes. By this, we mean the negative cliché and attitude based on untrue ideas that have been around us for thousands of years. Women tend to be stereotyped in a limited series of roles: mothers, housewives, tailors and nurses. However, today these clichés are obsolete gender stereotypes. Today, everyone knows that girls do not have to be housewives but can be corporate leaders or firefighters, while men can nurture babies without shame. The writers of the textbooks have presented females having limited occupational roles because they may have been influenced by these baseless clichés. Gender stereotypes are dangerous for people who are the target of these stereotypes because they can change people's destiny. If females believe them, they may become a nurse or tailor and they may be deprived of becoming a firefighter or a miner.

The most satisfactory solution to the problem may be a critical pedagogy after all, a pedagogy informed by critical social theory that "seeks to understand and critique the historical and sociopolitical context of schooling and to develop pedagogical practices that aim not only to change the nature of schooling, but also the wider society' (Pennycook, 1990, p. 24). It is concerned about how language can affect personal and social change. In other words, 'it results from personal and social choices that reflect a desire to understand both the word (i.e., language) and the world and to act upon these choices.' In second language classrooms, therefore, 'language can become a primary medium by which this may occur' (Crookes \& Lehner, 1998, p. 32). Besides, Fairclough, as cited in Graddol, Cheshire \& Swann (1994, p. 220), has argued that language teachers need to adopt a more critical stance towards traditional sociolinguistic studies which tend only to describe what happens in a speech community as appropriate. Language classrooms can thus provide a forum for critical analysis in which both students and teachers can question issues of language, power, discrimination, etc. However, the problem is that many language teachers believe in leaving their political proclivities and social ideologies outside the classroom. There are, we hope, few teachers who feel compelled to be neutral on the subject of sexism.

\section{Conclusion}

Some education experts claim that textbooks as part of the curriculum are replete with different kinds of discrimination and negative attitudes toward different groups of people, i.e., women, children, the old, the disabled and so on (Graci 1989, p. 79 ). Thus, this study aimed at investigating one of these, that is, gender bias in Iranian high school textbooks. The results of study revealed that:

1) Women were less visible than females both in texts and pictures.

2) Males work in more diverse occupational roles than females as represented by the textbooks. 


\section{Pedagogical implications}

The result of this research will be of great interest to syllabus designers who are interested in improving the quality of sex equality in the content and pictures of the textbooks. It is essential for syllabus designers to take into account the learners' sex equality in all forms. Indeed, the instructional objectives of an educational program are not achieved unless syllabus designers take into account the sex equality, human right and social justice.

In this regard, syllabus designers can take advantage of this study as it reveals the points that the content contains strong discrimination against females, and the pictures are gender biased pictures. Thus, a considerate syllabus designer should pay close attention to the issues of gender and equality. In brief, syllabus designers are advised to keep a balance between male and female characters, occupational roles, social activities, and the frequency of males and females' pictures.

\section{References}

Ansary, H. \& E. Babaii. (2003). On the manifestation of subliminal sexism in current Iranian secondary school ELT textbooks. Iranian Journal of Applied Linguistics, 6, 57-69.

Birjandi, P., N. Noruzi \& G. Mahmoodi. (2006). English 1. Tehran: Ministry of Education, Center for the publication of Iranian Textbooks.

Birjandi, P. \& A. Anabi. (2006). English for the Pre- University students.Tehran: Ministry of Education, Center for the publication of Iranian Textbooks.

Bolinger, D. (1980). Language - the loaded weapon: The use and abuse of language today. London: Longman.

Byrd, P. (2001). Textbooks: Evaluation for selection and analysis for implementation. In M. Celce-Murcia (Ed.), Teaching English as a second or foreign language. ( ${ }^{\text {rd }}$ ed.) (pp. 415-424). Boston: Heinle \& Heinle.

Cameron, D. (1990). The feminist critique of language: A reader. London. Rutledge.

Cameron, D. (1992). Feminism and linguistic theory. ( $2^{\text {nd }}$ ed.). London: Macmillan. http://dx.doi.org/10.1177/0959353592023026

Cohen, L. \& L. Manion. (1992). Research method in education ( $3^{\text {rd }}$ ed.): London: Rutledge.

Crawford, J. (2002). The role of material in language classroom: Finding the teaching . In J. C. Richards \& W. A Renandya (Eds), Methodology in lamguage teaching: An anthology of current practices (pp.80-98). Combridge: Cambridge University Press.

Crookes, G. \& A. Leehner. (1998). Aspects of process in an ESL critical pedagogy, teacher education course. TESOL Quarterly, 32, 319-328. http://dx.doi.org/10.2307/3587586

Delianni-Kouimitz, K. (1992). Father is out shopping because mother is at work:Greek primary school reading as an example of educational policy for gender equality .Gender and Education,4,67-79.

Einser, E. (1985). The educatoinal imagination ( $2^{\text {nd }}$ ed.).New York: Routledge.

Fairclough, N. (1989). Language and Power. New York: Longman.

Gharbavi, A. \& Mousavi, S. A. (2012). The application of functional linguistics in exposing gender bias in Iranian high school English textbooks. English language and Literature Studies, 2 (1), 85-93.

Graddol, D., I. Cheshir \& J. Swann. (Eds.). (1994). Describing Language. Buckingham: Open University Press. http://dx.doi.org/10.5539/ells.v2n1p85

Graci, J.P. (1989). Are foreign language textbooks sexist? Exploration of models of evaluation. Foreign Language Annals, 22, 77-86. http://dx.doi.org/10.1111/j.1944-9720.1989.tb02771.x

Hall,D.R \& A.Hewing.(eds) (2001). Innovative in English Language Teaching . London Routledge.

Hartman, P.L. \& E.L. Judd. (1978). Sexism and TESOL materials. TESOL Quarterly, 12, 383-393. http://dx.doi.org/10.2307/3586137

Kadivar, J. (2002). Zan [woman]. Tehran: Ettal'at Publication.

Kemp, J.E. (1977). Instructional design: A plan for unit and course development ( $2^{\text {nd }}$ ed.). New York: Longman.

Lesikin, I. (2001). Determining social prominence: A methodology for uncovering gender bias in ESL textbooks. In D. R. Hall \& A. Hewing (Eds), Innovation in English Language Teaching (pp.275-282). London: Rutledge.

Pauwels, A. (1998). Women changing language. London: Longman. 
Pennycook, A. (1990). Towards a critical applied linguistics for the 1990s. Issues in Applied Linguistics, 1, 8-28.

Peterson, S. \& Kroner. T. (1992). Gender biases in textbooks for introductory psychology and human development. Psychology of Women Quarterly, 16, 17-37. http://dx.doi.org/10.1111/j.1471-6402.1992.tb00237.x

Porreca, K. L. (1984). Sexism in current ESL Textbooks. TESOL Quarterly, 18, 704-707. http://dx.doi.org/10.2307/3586584

Reese, L. (1994). Gender equality and texts. Social Studies Reviews, 33, 12-15.

Stearns, P. N. (2000). Gender in world history. London: Rutledge.

Table 4.1 Frequency of male and female visibility in the text of all the four books in 2006

\begin{tabular}{|l|l|l|l|l|l|l|}
\hline \multirow{2}{*}{ Book title } & \multicolumn{2}{|l|}{ Male } & \multicolumn{2}{l|}{ Female } & \multicolumn{2}{l|}{ Total } \\
\cline { 2 - 7 } & F & $\mathbf{\%}$ & F & \% & F & \% \\
\hline English Book 1 & 161 & 74 & 57 & 26 & 218 & 100 \\
\hline English Book 2 & 107 & 69 & 49 & 31 & 156 & 100 \\
\hline English Book 3 & 136 & 71 & 56 & 29 & 192 & 100 \\
\hline Pre-university English Book & 44 & 65 & 24 & 35 & 68 & 100 \\
\hline Total & 448 & 71 & 186 & 29 & 634 & 100 \\
\hline
\end{tabular}

Note 1: All percentages are rounded to the nearest whole number so that they add up to $100 \%$.

Note 2 : $\mathrm{F}=$ Frequency, $\%=$ Percentage

Table 4.2 Frequency of male and female visibility in the Pictures of all the four textbooks in 2006

\begin{tabular}{|l|l|l|l|l|l|l|}
\hline \multirow{2}{*}{ Book title } & \multicolumn{2}{|l|}{ Male } & \multicolumn{3}{l|}{ Female } & \multicolumn{2}{l|}{ Total } \\
\cline { 2 - 8 } & F & $\mathbf{\%}$ & $\mathbf{F}$ & $\mathbf{\%}$ & F & $\mathbf{\%}$ \\
\hline English Book 1 & 103 & 77 & 31 & 23 & 134 & 100 \\
\hline English Book 2 & 80 & 78 & 23 & 22 & 103 & 100 \\
\hline English Book 3 & 78 & 70 & 35 & 30 & 113 & 100 \\
\hline Pre-university English Book & 23 & 92 & 2 & 8 & 25 & 100 \\
\hline Total & 284 & 76 & 91 & 24 & 375 & 100 \\
\hline
\end{tabular}

Table 4.3 Frequency of male and female occupational roles in all the four textbooks in 2006

\begin{tabular}{|l|l|l|l|l|l|l|}
\hline \multirow{2}{*}{ Book title } & \multicolumn{2}{|l|}{ Male } & \multicolumn{3}{l|}{ Female } & \multicolumn{2}{l|}{ Total } \\
\cline { 2 - 8 } & F & $\mathbf{\%}$ & F & \% & F & $\%$ \\
\hline English Book 1 & 29 & 83 & 6 & 17 & 35 & 100 \\
\hline English Book 2 & 16 & 95 & 1 & 5 & 17 & 100 \\
\hline English Book 3 & 19 & 74 & 7 & 26 & 26 & 100 \\
\hline Pre-university English Book & 7 & 78 & 2 & 22 & 9 & 100 \\
\hline Total & 71 & 82 & 16 & 18 & 87 & 100 \\
\hline
\end{tabular}


Table 5.1 Chi-square test for sex category and visibility in reading passages

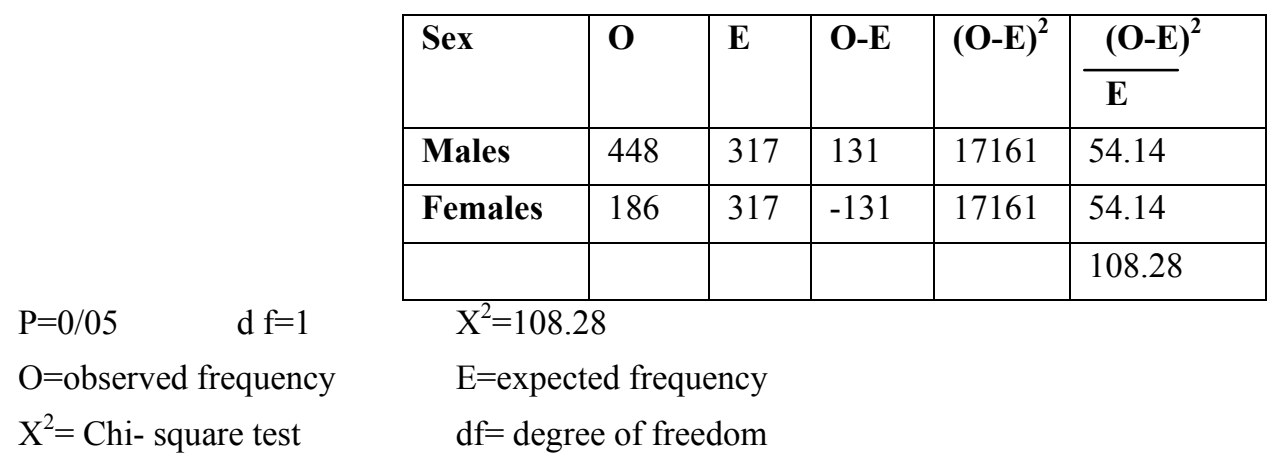

Table 5.2 Chi-square test for sex category and visibility in the pictures

$\mathrm{P}=0.05$

\begin{tabular}{|l|l|l|l|l|l|}
\hline Sex & O & E & O-E & $(\mathbf{O - E})^{2}$ & $(\mathbf{O - E})^{2}$ \\
\cline { 5 - 6 } & & & & & $\mathbf{E}$ \\
\hline Males & 284 & 187.5 & 96.5 & 9312.25 & 49.67 \\
\hline Females & 91 & 187.5 & -96.5 & 9312.25 & 49.67 \\
\hline & & & & & 99.34 \\
\hline
\end{tabular}

Table 5.3 Chi-square test for sex category and male/female occupational roles

\begin{tabular}{|l|l|l|l|l|l|}
\hline Sex & $\mathbf{O}$ & $\mathbf{E}$ & O-E & $(\mathbf{O - E})^{\mathbf{2}}$ & $\mathbf{( O - E )}^{\mathbf{2}}$ \\
\cline { 4 - 7 } & & & & & $\mathbf{E}$ \\
\hline Males & 71 & 43.5 & 27.5 & 756.25 & 17.38 \\
\hline Females & 16 & 43.5 & -27.5 & 756.25 & 17.38 \\
\hline & & & & & 34.76 \\
\hline
\end{tabular}

$\mathrm{P}=0.05 \quad \mathrm{df}=1 \quad \mathrm{X}^{2}=34.76$ 